\title{
THE LIFE STRUGGLE OF FEMALE CHARACTERS IN THE NOVELS OF ABIDAH EL KHALIEQY
}

\author{
Yenny Puspita ${ }^{1}$, Zainal Rafli ${ }^{2}$ \\ PGRI University of Palembang ${ }^{1}$, Universitas Negeri Jakarta ${ }^{2}$ \\ yenny_puspitaa@yahoo.com ${ }^{1}$, zainalrafli@unj.ac.id ${ }^{2}$
}

\begin{abstract}
This study aimed to obtain a deep picture and understanding of the life struggle of female characters in the novel written by Abidah El Khalieqy. The research design used was descriptive qualitative with feminism approach. The data in this research were the study results of the novel documents of Perempuan Berkalung Sorban and Geni Jora by Abidah El Khalieqy in the form of words, sentences in the form of utterances, description of figures and inter-character dialogues indicating the existence of feminism that happened to the analyzed figures of the novel. The procedure in analyzing research data was content analysis. The data validity analysis utilized triangulation technique. Based on the results of research and discussion, it was found that the struggles to fight the injustice among them were the struggle against: 1) marginalization of women; 2) subordination to women; 3) stereotypes about women; and 4) violence against women, including the struggle against physical, sexual and psychological violence; and 5) the struggle against women's workload.
\end{abstract}

Keywords: life struggle, female character, feminism.

A literary work can be viewed as a portrait of human life. In the literary work, the author presents the model of life and social conditions of the characters which include social structure, social relations, social contradictions, kinship relations, strong group dominance of the weak and other social life sides like real life. Thereby, appreciating and understanding literary works are the same as living and understanding human and their life in all aspects which in fact can be studied by human- related disciplines. Literary works are the media used by authors in conveying their ideas. As a medium, literary work becomes a bridge that is conveyed to readers.

Novels as one of the media in the ideological struggle at the cultural level can be a significant basis for understanding feminism. Novel is created with a variety of purposes about the existence of women in various cultural contexts as well as with the various perspectives of women and their world. The placement of women's positions in the lower and less powerful places exists because of patriarchy, a system that allows men to dominate women in all social relationships. In a patriarchal culture, there is no world for women outside marriage. The institution of marriage is a cultural space created with a strong myth for men's interests. Now, women need to be quite happy and relieved, because they are no longer merely seen as an object of physical beauty to be seen and enjoyed, but they have been seen as a multi-dimensional and qualified humannoble.

Feminist literature is rooted in an understanding of the inferiority of women. The key concept of feminists is equality between the dignity of women and men. The rise of many Indonesian women authors in recent years, the rise of female readers and the frequent presence of female characters in Indonesian literature deserve to be observed in the context of applying feminist literary criticism.

In this study, the author chose the work of Abidah El Khalieqy. Some of Abidah El 
Khalieqy's works are best seller. The results of her writings had gained national recognition, especially for the category of female authors. In her works, Abidah more dominantly raised feminist issues with the background of boarding school life. This research focused on the novel text which were limited to the feminism problem in the novels Perempuan Berkalung Sorban (2001) and Geni Jora (2004) written by Abidah El Khalieqy. Both novels featured attractive, complex and dynamic female characters that deserved to be investigated.

The selection of the Perempuan Berkalung Sorban and Geni Jora novels by Abidah el Khaileqy as the object of research was based on actual and relevant issues with contemporary life that would be useful for organizing a better future, especially for women. In addition, the novel Perempuan Berkalung Sorban and Geni Jora by Abidah el Khaileqy could be used as teaching material as a model of gender-based literary learning. This study examined several issues related to women's view of life, forms of injustice against women and the struggle of women leaders. This study aimed to see the position of women in the middle of patriarchal cultural system that existed in the novel based on feminism perspective. This research was conducted to get a deeper description and understanding about the life struggle of female characters in the novels of Abidah El Khalieqy.

Feminism was born in the early 20th century pioneered by Virginia Woolf (2013) that feminism is derived from the word femine (woman) meaning a woman (singular) which aims to fight for the rights of women (plural) as a social class. Furthermore, Thornham (2000: 38) considered women to be inside and outside all the symbolic structures that make up identity. Women are out of the nation because they themselves can not claim a national identity. They are outside the class because they do not have a class marker. In the material sense, women are confined in the private sphere excluded from social power, but their ideological power is much greater.

Gender differences will not be a problem as long as it does not give rise to gender inequalities. However, gender differences have generated gender inequality, especially to women. Manifestations of gender inequality occur in various forms in the economic, political, social and culture (Fakih, 2003: 12). On the other hand, Sugihastuti and Suharto (2010: 18) said that feminism is a movement of equality between men and women in all fields, political, economic, educational social or organized activities that defend women's rights and interests. Feminism is an awareness of oppression and extortion of women in society both in the workplace and at home.

Sugihastuti and Suharto (2010: 18) say that feminism is a movement of equality between men and women in all fields, political, economic, educational, social or organized activities that defend women's rights and interests. In the development, injustice happen to women merged in the literary work because the dominance of patriarchal culture is the production and acceptance of literary works in the hands of men. Most literary works are written and also criticized by men (Hellwig, 2003: 10-11). In a literary world full of imaginary, characters of male characters are portrayed as someone who possesses heroic traits and of course, the depictions of women fit their imaginations as well. A female hero can be a heroine if it is in accordance with the concepts that men have determined.

Critics of feminist literature have an important goal of feminist literary criticism, which is to help the reader understand, describe, interpret and judge the works written by authors (Djajanegara, 2000: 27). Thus, feminist discourses have changed the approaches to all literature, and that the integration of women's voices has developed. Although it seems that up to now feminist literary criticism has not made as much change as needed yet. The subsequent development is feminist literary critics also paid attention to women as writers.

\section{Feminism Study}

To date, various juridical activities and instruments have been established to support the realization of Gender Equality and Justice (Kesetaraan dan Keadilan Gender) in Indonesia. The 
government's commitment through the Ministry of Women's Empowerment to bring gender equality and justice into reality is very high. The Government of Indonesia ratified by law No. 23 of 2004 on the Elimination of Domestic Violence (PKDRT) which provides protection for victims of violence and criminal sanctions for the perpetrators. The development of women's studies related to the paradigm underlying the struggle or demand for gender concerns in Indonesia is outlined below: (1) the concept of Women in Development (WID), (2) the Gender and Development Concept, (3) the Concept of Gender Women Empowerment (PUG ) Or Gender Mainstreaming (Cleves, 2007: 21 -30).

In Nugroho's view (2008: 40), gender inequality is a system and structure for men and women to be victims of the system. This view illustrates that gender is one of the key social structures of contemporary culture and is characterized by power struggles and injustices. Gender and inequality hierarchies are maintained among other factors, with meaning and belief systems, and this alters results through representation. Representation is built through language, image, social practice, material and symbol dimensions. Still on the similar perception, Sugihastuti (2000: 113-121) gives an overview of the role of women in everyday life, whether at home or outside, every woman has her own choice and is responsible for her own desires. The role of the female character is part of the main task that must be performed as a woman. There are various roles that she has from birth to adulthood, such as being a wife, as a mother, and as a parent. The roles that she possessed are part of her life as a woman.

\section{Women's Struggle}

Gender studies related to the concept of women's empowerment promote gender equality and empower women as an effective way to combat poverty, hunger and disease. This was done to meet the practical and strategic needs of women. The fulfillment of women's practical needs involves the need for women to carry out social roles to meet short-term needs such as improving living standards, improving health services, providing employment, illiteracy eradication and so forth.

1. Marginalization of Women

According to Muniarti (2004: 20), marginalization is placing or shifting women to the periphery. Women are imaged weak, lacking or irrational, lacking or daring, so inappropriate or unfit to lead. As a result, women are always secondary whenever there is a chance to lead. What is meant by marginalization is the process of impoverishing women so that women cannot act and express because the role of women is shifted to the margins or marginalization of women positions socially in the acquisition of economic and political resources both in the domestic and public sphere.

2. Subordination toward Women

Sunarto (2009: 139) states that subordination is an effect arising from the dominant position of men over women acquired through physical violence, coercion, structural violence (done by social institutions and economic power), and symbolic violence. Thus, subordination is defined as a social process in the life of a society that raises a policy on women so that it does not consider that women are important which position women and their work lower than men.

3. Gender and Stereotype

Stereotypes are the labeling or marking of a particular group. A stereotypical view is a standard image of an individual or group that is inconsistent with existing empirical reality. Negative labeling (stereotypes) generally generates gender inequality. Gender-role stereotypes are common categories that describe views and beliefs about women and men (Santrock, 2003: 374). Thus, stereotyping is the labeling or negative labeling of a people with all forms of representation of the beliefs of society.

4. Gender and Violence

Many kinds and forms of crimes can be categorized as gender violence, including: the form 
of female rape, including rape in marriage;

Acts of beatings and domestic violence; Forms of genital mutilation; Violence in prostitution; Violence in pornography; Violence in KB settlement; Veiled violence; Sexual violence (Fakih, 2003: 20). Violence against women is an attack carried out because of the gender assumption that makes women as victims of domestic violence, whether physical, psychic, economic neglect, and sexual violence

\section{Workload}

Nugroho (2008: 47) argues that women's gender roles in the public's assumption is managing the households so that many women bear the domestic workload more and longer than men. In fact, for the poor families, the burden must be borne by women in addition to working outside so that they should bear a double workload. For community groups with sufficient economic levels, domestic workloads are often assigned tohousemaids

\section{METHOD}

This research used descriptive qualitative design. The researchers described systematically, factually, and accurately about the studied facts and causal relationships of the phenomena. Data obtained in this study were through explanation, speech figures or attitude, or the thought that Abidah El Khalieqy would like to convey through his novels.

The study relied on inter subjectivity assumptions and generally created the meaning and "reality" between researchers and participants.

The data in this research were the result of study of novel document of Perempuan Berkalung Sorban and Geni Jora by Abidah El Khalieqy in the form of words, sentences in the form of utterances, description of figures, and inter-character dialogue which indicated the existence of feminism that happened to the analyzed novel figures. The data analysis procedure used in this research was content analysis. Content analysis also analyzed not only the manifest nature of a text as Mayring (2000) says: "Content analys is not only the manifest content of the material-as its name suggests". When referring to Mayring, content analysis also emphasizes on the data interpretation.

Data validity analysis used triangulation technique. There are two forms of triangulation to check data in theoretical triangulation.

\section{RESULTS AND DISCUSSION}

\section{The Life Struggle of Female Characters in the Novels of Abidah El Khalieqy}

1. The Life Struggle of Female Characters in the NovelPerempuan Berkalung Sorban

a. The Struggle against Marginalization toward Women

The struggle against the marginalization of women in the economic field as a process of marginalization of women's position socially with the aim of impoverishing women so that women cannot act and expression of the role that is shifted from where it can be achieved. It was then opposed by Annisa figure in the novel Perempuan Berkalung Sorban.

In the economic field, Annisa wanted to be able to work and had her own income. By working, each at the beginning or the end of the month she would receive a salary. She did not want to depend on men.

"And if I go to the office, my shirt is fragrant and neat unlike Lek Sumi all day in the kitchen, his body smells and her clothes are oversized. If I go to the office, everyone looks at me with respect, does not cover their nose if I pass as they cover their nose near Lek Sumi, because of the smell of onions and shrimp paste. And at the end of the month the account receives a 
salary. " (Perempuan Berkalung Sorban, p. 15)

Annisa held that if she went to the office, her clothes were neat and tidy unlike Lek Sumi who was all day in the kitchen, her body smelled and her clothes were oversized. If Annisa went to the office, everyone looked at her respectfully, did not cover their nose if she passes as they closed their nose near Lek Sumi because of the smell of onions and shrimp paste.

After marrying Samsudin, the man of his parents' choice, Annisa in her household did not have the right to organize finances, organize shopping, and all hou sehold necessities, as well as her personal needs. Financial affairs submitted to his second wife, namely Mbak Kalsum. For this reason, Annisa then talked to Samsudin so that he split the money in a fair way just as the sunnah of polygamy. Annisa demanded her right to get her birthright as a wife.

After I think about it, I talked to Samsudin as well so that he split the money in a fair way just as the sunnah of polygamy. He said he would show me justice someday. (Perempuan Berkalung Sorban, p.118)

In the political sphere, women can have the same rights as men to express opinions, both for themselves, within the scope of the family and the larger area, the political rights in society and the state. In the domestic sphere, women also have the right to refuse, accept, or initiate in intimacy with their husbands.

A wife also has the right and freedom to refuse and accept. (Perempuan Berkalung Sorban, p. 139)

Annisa's body always held rejection, as well as her soul while in touch with Samsudin. Annisa never felt ready when invited to have sex with Samsudin. When women were not ready, for Annisa it hurt, even abused. However, Annisa has not dared to refuse. She is gathering strength. One day later, Samsudin will be shocked, also many people would be shocked to see what Annisa would do in the future.

b. The struggle Against Subordination towardWomen

In the novel Perempuan Berkalung Sorban there was subordination that had placed the female characters in positions not important and never taken into account. The various forms of subordination that were handed down to women made the Annisa figure as the main character in the novel to bring up the ideas of gender equality championed by it. Annisa was fighting for her right to subordination, in determining decisions in her life like men. Annisa had proved herself that she was capable of doing great

things, as high as anything she could achieve, even beyond what men could achieve.

Although it has passed, far behind the time, childhood saved much story. Sometimes fun, but more annoying. And now that I've got the title, I have Mahbub, my only child, that story often appears in accordance with the knowledge I got from the sheets of life book. (Perempuan Berkalung Sorban, p. 1-2)

Annisa wanted to be a free woman, not in the confines of anyone, not even a man. She wanted to be a smart woman, as her name implies, not to be a foolish woman that could be lowered by men. Annisa wanted to be able to answer questions asked by her brother Rizal about the differences between humans and frogs and other reasons not to catch the females in trouble

Annisa had a desire to ride a horse. Her desire to learn to ride a horse had surpassed the supreme tone of his father's anger. Annisa was forbidden to ride a horse because she was female, the ability to ride a horse only deserves to be owned by a man. However, Annisa thought otherwise that she had the same right to be able. To realize that desire, she trained to ride the horse with her uncle, 
namely Lek Khudhori.

"Yes, why, Pak? I can't? Kak Rizal also learned to ride horses. " (Perempuan

Berkalung Sorban, p. 7)

Annisa thought that whatever happened she must be able to learn to ride a horse. She would still learn to ride horses. Annisa's dream of being able to ride a horse was to equate her as Aisha or Princess Budur who could lead a war army, to be like Tjut Njak Dhien who was also great, also wanted to be great as Queen Balqis or Hindun bint Athaba. Moreover, as a leader means that other people would be subservient. In fact, the mighty men became obedient behind her.

c. Struggle Against Stereotypes about Women

The form of struggle against stereotypes against women was to change the negative labeling of her people. The struggle of women in thenovel Perempuan Berkalung Sorban to fight the stereotype of which championed by Annisa

"I know gendher, if it is fried, it will be so salty crackers, ha ha .." "Pinhead! I Always outdated, "I scoffed,

"What is feminism. What is gender? What do you know about patriarchy? You are a wiseacre, Zal, Rizal." (Perempuan Berkalung Sorban, p.173)

Labeling as a form of stereotypes about women who are always considered stupid even loudly thrown at her brother. She called Rizal the 'pinhead'. The pinhead means a fool. The negative stigma that women are stupid was opposed by Annisa.

d. The Struggle Against Violence towardWomen

In the novel Perempuan Berkalung Sorban there are various struggles against violence toward women such as the struggle against physical violence, the struggle against sexual violence and the fight against emotional violence. This can be seen in the following description.

1) The Struggle against Physical Violence

Physical violence that occurred in the novel Perempuan Berkalung Sorban which happened to Annisa as the main character of women in this novel is a follow-up of sexual violence perpetrated by Samsudin, her husband.

I was about to scream, but lost quickly with the palm of his hand that silenced my mouth. (Perempuan Berkalung Sorban, p. 97) "Fine! Fine! ... But marriage can not be based on a single disease. Therefore I will punch you. Do you hear now?"

"Second, you have hurt me for so long and tried to transmit your disease to me. But Allah guards me from your tyranny. So to Allah I give a worthy reply to your violence and the third ... " (Perempuan Berkalung Sorban, p. 114-115)

The quotation above illustrates the physical struggle or resistance to physical violence against women. Annisa could not retaliate through physical resistance. What Annisa could do was to protest against any kind of harsh treatment of Samsudin against her. Annisa whose physical, mind, and heart was tortured felt no longer strong against Samsudin, she was about to divorce Samsudin. Annisa's anger and hatred for Samsudin reached its peak when the physical violence that happened to her was also experienced by Mbak Kalsum, her co-wife, and Fadilah, Samsudin's daughter with Mbak Kalsum.

2) The Struggle against Sexual Violence

Annisa's struggle to fight sexual violence was when she always got contumely from her husband, Samsudin. Samsudin always asked for his rights without seeing the condition of his partner. Samsudin always insisted, even raped Annisa every time of having sex. 
"... Indeed up to now I have not dared to express the rejection verbally, because I myself have not got clarity about the law ...." (Perempuan Berkalung Sorban, p. 139)

"... But if I hurt his heart, I can not stand his savagery, is that justified by religion?" (Perempuan Berkalung Sorban, p.169)

Annisa attempted to counteract abusive behavior and abuse against her through attitude and behavior. However,, Annisa has not dared to express the rejection of Samsudin request verbally because she has not got clarity about the law in Islam. Annisa's body always held rejection, as

well as her soul while in touch with Samsudin. Annisa never felt ready when invited to have sex with Samsudin. When women were not ready, for Annisa it hurt, even abused.

3) The Struggle against Emotional / PsychicViolence

Annisa's form of resistance in her struggle against psychic/emotional violence was by opposing all kinds of psychic violence she experienced frontally, directly to the target object. For example, at the beginning of the story Annisa got a statement that offended her, namely statement and question from Pak Joko, Nisa's Indonesian teacher who compared himself to Lek Khudhori. Annisa considered that Lek Khudhori could not be compared to anyone, with any party. She replied to a statement from Mr. Joko that she would be really angry and hoped not to try to be wiseacre about Lek Khudhorianymore.

"No! Lek Khudhori can not be compared to anyone, with any party, also with the father. You must know that and do not try to be knowledgeable about him. I will be really angry!" (Perempuan Berkalung Sorban, hal. 58)

Lek Khudhori became a role model and model for Annisa. He could not be compared to anyone, not even Mr. Joko, Nisa's Indonesian teacher or her own husband, Samsudin. Only Lek Khudhori can keep me at ease and happy. The statement that Annisa threw to avenge her heartache. e. Struggle against Workload forWomen

Overloaded or double burden due to stereotypes and subordination caused the woman's role to increase (being a working woman or a career) then her charged domestic role must be arranged to divide it

proportionally. The struggle must be manifestly realized in the household. Women who participate in struggling for the equality of workload in the household are voiced by Annisa. Since childhood, Annisa considered that in matters of domestic work it is not fair.

The duties of a woman are numerous, there are washing, cooking, ironing, mopping, sweeping, breastfeeding, feeding, bathing her child, and more. Unlike men, Mom, just one, going to the office. (Perempuan Berkalung Sorban, hal. 14)

According to Annisa, the duties or responsibilities that women have to do in the domestic sphere are numerous, including washing, cooking, ironing, mopping, sweeping, feeding, breastfeeding, bathing their children, and others. Unlike men, only one, ie go to the office. For Annisa, the Woman's nature is just pregnant, giving birth, and breastfeeding her child. For the business of washing, cooking and educating the child are husband's responsibility as well. Associated in terms of having sex, both husband and wife have the right to feel pleasure in the relationship of husband and wife. So, it is not the wife's duty only, but also the obligation of the husband to make the wife happy.

\section{The Life Struggle of Women in the Novel of GeniJora}


a. The Struggle against Marginalization toward Women the Novelof Geni Jora

The root of gender inequality is related to patriarchal culture. In fact, not a few women who are qualified in various fields in the public space, not just adept at playing her role as mother and wife. In the political sphere for example, women can have the same rights asmen.

"As in a fairy tale, the queens of Malikah, Khatun, they appeared little by little from the soft moans of yellowing pages in ancient books ... they appeared ... abdicating the throne from mother to daughter." (Geni Jora, hal.28)

In the field of politics and government, women have equal opportunity to occupy certain positions, for example being the leader of the kingdom that does not have to be dominated by men. The queen of Malikah, Khatun became ruler of the royal throne to then abdicate the throne to her daughter, not to the son who became her crown prince

b. The struggle Against Subordination towardWomen

In the Geni Jora novel there was a subordination that placed the female characters in unimportant positions and had never been taken into account. The various forms of subordination that were handed down to women made the Kejora angry against men so that the ideas of gender equality were championed by her. Kejora needed to fight for her rights and freedom in determining decisions in her life as a woman like men.

As a student, as a santriwati, as a colllegian, I sat facing each one. I installed my hearing in focusing my eyesight. I absorbed knowledge with my brain and my fuad. I learned science to meet the nutritional growth of my life. So I stand now, in front of you my ustad (Geni Jora, p.48).

The above quotation illustrates how the figure of the Kejora struggled the subordination done by her grandmother. Kejora did the struggle by continuing to welcome the future, that is by continuing to study diligently. It can be seen from the way she learned to read books, holy books and speeches of kyai as well as paid attention to teachers' explanations.

There is nothing in vain from rebellion. And nothing lasts from injustice. It always bears rebels with different types and models. And I think eradicating injustice is with a mirror on the face of the protagonist. (Geni Jora, page268)

There are still many women undergoing subordination so that their position can not be equal with men. Women are always not considered important. It is evident that men, especially those who are still in a patriarchal environment, are always considered to be superior and first class. Unlike women, the condition of women who are in a superior position has never been taken into account. However, in today's development it can not be applied to women because women today tend to rebel. Their rebellion was not merely a resistance. However, the rebellion is a form of genderstruggle.

Kejora wanted to be an independent woman just like free men without any restraint. However, it was with politeness and good way. She wanted to run her like a man running his life with work and education on the same portion. Based on this, Kejora indicated that she did not want to be a victim of subordination that had curbed and discriminated women.

c. Struggle Against Stereotypes about Women in the Novel of Geni Jora

One form of this stereotype is sourced from a gender perspective. There are so many stereotypes that occur in society that are attached to women generally so that they cause complicating, limiting, impoverishing, and disserving women. 


\section{"Big fish in a little sea," replied Firouz calmly. "Pity and shame!" (Geni Jora, p 29)}

Negative labeling (stereotypes) in the view of feminism is aimed at women. The above quote is the opposite; men who scoffed at women's ideas about gender equality were opposed by men in discordant voices, the voice of less confident men in women-themed environments. Women who have 'stupid' stereotypes turn things around to narrow-minded men, jealous of women. So women are the pearls of gold, and the jewels of the world, the objects of interest to be envied, assaulted, and robbed of primitive male desires.

Kitchen and miniskirts are no longer the trademarks of wives. (Geni Jora, p.156)

Stereotypes about women that women are tempting faith creatures with their 'mini skirts'. Mini skirts can be interpreted as cheap, paid women, easily accessible in many places by the masses. For Kejora, the trademark is no longer valid. For her, women can be more than that. Able to be anything, higher than what men canachieve.

d. The Struggle against Violence toward Women in the Novel of Geni Jora

In the novel of Geni Jora, there are various struggles against violence against women such as the struggle against physical violence, the struggle against sexual violence, and the fight against emotional violence. This can be seen in the followingdescription..

1) The Struggle against PhysicalViolence

Ayeda and Fashafasha were true female warriors who took part in fighting for Palestinian land over Israeli occupation and its allies. For Ayeda and Fashafasha, martyrdom is a dream, a desire, and an ambition.

"But we're not just in between," Fasha corrected, smiling, "we're part of them. Martyrdom is a dream, a desire, and an ambition. That's all my dream, "explains Fashafasha. (Geni Jora, p37)

The quotation above illustrates the physical struggle or movement of the Palestinian resistance against the Israeli arbitrariness that occupied Palestine so that their freedom was forcibly taken away. For that, all the people were constantly moving Mossad, elderly people, young people, children and even women fight for their homeland, Ayeda and Fashafasha are equally active in Harakah Al-Muqawwamah Al Islamiyah, abbreviated as 'Hammas'. Hammas had a sophisticated, highly confidential operating method, and is capable of striking and very strikingoperations.

2) The Struggle against SexualViolence

Fighting for gender justice is a tough task, because gender issues are an intense issue, for everyone who is emotionally involved. There are a lot of resistance when the struggle for gender inequality is activated because it is also a matter of challenging the privileges that a person gets from genderinequality.

"No!" I shrieked loudly, "what will Uncle do to me! Let go of my hands! Let go! "I yelled that made Uncle bling wanted to run away, but where? Grandmother was at the door of the room and found us alone together. (Geni Jora, p. 111)

That Lala being harassed by his two uncles made Kejora disliked because that behavior made Lala looked miserable. Therefore, Kejora wanted to help her. Then she slammed the door till it was crackling to surprise his two uncle and managed to escape Lala. Sexual harassment by uncle was also experienced by Kejora. Because of the actions of her uncle, Kejora tried to fight him byshouting. 3) The Struggle against Emotional/PsychicViolence

Emotional violence was also experienced by Kejora. Kejora experienced emotional violence 
because of Zakky's behavior. Zakky, Kejora's boyfriend, was a masher. It was shown by the behavior he did. Zakky's behavior when meeting Lala, the way he looked at her, touching Lala's fingers even he would meet her in Jogjakarta in December illustrated Zakky's masher attitude that made Kejora jealous and sad. It is deeply described asfollow:

“.....Independent. Trying to adapt politely and move. If men love to hunt there is nothing wrong women like the same thing. "(Geni Jora, p. 22)

Emotional violence has affected the psychological condition of the victim. In the Geni Jora novel the emotional violence raised psychological conditions of inner pressure and jealousy towards men. Such conditions

were experienced by Kejora's mother and Kejora. Kejora's mother who was made second wife by his father so that less attention from his father made her soul depressed. Kejora was very opposed to the practice of polygamy. She did not want to have the same fate as her mother, as a victim of male abuse. It was stated when she was talking to Najwa, Zakky'ssister.

"What if Zacky did polygamy, what is your reaction?" Ask Najwa "I will do polyandry in illegal ways". (Geni Jora, p.192)

The above quotation was the thought of the Kejora about justice delivered when answering the Najwa question. The right of equality and justice in the opposite sex relationship specifically was having more than spouses as well as Muslim men who were allowed to practice polygamy. Kejora fought it in a similar way, but not the same. Kejora would do polyandri using legal ways, namely to divorce Zakky, then remarried with a movie star that was more handsome than Zakky. Polyandry or not, the important thing was fair. If men could do it, women could do it as well. Therefore, Kejora opposed polygamy. Her struggle for equality appeared in her thinking that women could practicepolyandry.

e. The Struggle against Women'sWorkload

Overloaded or double burden due to stereotypes and subordination caused the woman's role increase (being a working woman or a career) then her charged domestic role must be arranged to divide it proportionally. The struggle must be manifestly realized in the household. The female characters in the Geni Jora novel who had championed the workload in the household were voiced by theKejora.

Nadia Masid, like Nishwa or Qadisha, is a today's generation who has enjoyed technological progress. Going to college and abroad for conferences. She is no longer a woman with her hands clasped with flour mixed tajin and kuskus. Nor was the woman with waving djellaba bringing a basket of dirty clothes going to the Onila River. (Geni Jora, page26)

The quotation quote above shows the struggle of equality in a double workload for women. She illustrated Nadia Masid, Nishwa, and Qadisha as the present generation who had enjoyed technological progress and could go to college and abroad to attend conferences. She was not a woman with her hands wrapped in flour mixed with tajin and kuskus. Nor was the woman with waving djellaba bringing a basket of dirty clothes going to the Onila River. It showed the struggle of equality in the acquisition of educational opportunities without the limitation of space and time for women so that she could develop herself and escape from manpower with a double workload.

\section{CONCLUSION}

Based on the results of the research and discussion, it was found that the struggle to fight the injustice are the struggleagainst: 
1) marginalization towardwomen;

2) subordination towardwomen;

3) Sterreotypes about women;and

4) Violence toward women such as struggle against physical, sexual and psychological violence, and

5) the struggle against women'sworkload. as follows:

Based on the conclusion and implication above, the researchers gave some recommendations

1. Through this research, literary works would no longer be seen as a strange thing for readers and readers were expected more able to absorb and enjoy a literarywork.

2. This research was expected to be utilized as an alternative material of theory and literary appreciation, which was to help the language skills, improve the knowledge of culture, develop the creativity and taste, and support the forming of the characters of learners.

3. In interpreting the content of the novel, students should be able to imitate the attitude and character of the character and absorb positive values as a guidance of life.

4. This research was expected to be useful for other researchers for the next research references when analyzing literary works, especially for feminism and gender equality studies with other approaches so it could increase the treasure resource of literary research.

\section{REFERENCES}

Cleves, Julia Mosse. Gender \& Development (translated by Hartian Silawati). Yogyakarta: Pustaka Pelajar, 2007.

Denzin, Norman K. \& Lincoln, Yvonna S. Handbook of Qualitaitive Research (Thousand Oaks, London, New Dehli: Sage Publications International Educational and Professional Publishers, 1994.

Djajanegara, Soenarjati. Kritik Sastra Feminis: Sebuah Pengantar. Feminism Literary Critics: An Introduction Jakarta: PT Gramedia Pustaka Utama, 2000.

Fakih, Mansour. Analisis Gender dan Transformasi Sosial. Gender Analysis and Social Transformation. Yogyakarta: Pustaka Pelajar, 2003.

Hellwig, Tineke. In The Shadow Of Change. Jakarta Selatan: Desantara, 2003.

Mayring Philip. "Qualitative Content Analysis" Forum Qualitatif Research Vol.1 No.2-June 2000, tersedia (daring), http://www.qualitative- research.net/ index.php/ fqs/article/view/1089/2385

Murniati, Nunuk P. Getar Gender (Buku Pertama). Gender Vibration (First Book) Magelang: Indonesia Tera, 2004.

Nugroho, Riant. Gender dan Administrasi Publik. Gender and Public Administration Yogyakarta: Pustaka Pelajar. 2008.

Ratna, Nyoman Kutha. Teori, Metode, dan Teknik Penelitian Sastra. Theory, Method and Technique of Literary Research Yogyakarta: Pustaka Pelajar, 2012.

Reinharz, Shulamit. Metode-metode Feminis dalam Penelitian Sosial Feminism Methods in Social Research (Jakarta: Woman Reseach Institute, 2005. 
Santrock, J.W. Adolescence Perkembangan Remaja: Edisi Keenam.Adolescence Growth: The Sixth Edition Jakarta: Erlangga, 2003.

Selden, Raman. Practicing Theory and Reading Literature. London: Harve ster-Wheatsheaf, 1989.

Sugihastuti \& Suharto. Kritik Sastra Feminis: Teori dan Aplikasi. Feminism Literary Critics: Theory and Application Yogyakarta:Pustaka Pelajar, 2010.

Sugihastuti. Perempuan Di Mata Perempuan. Women in the eyes of Women Bandung : Yayasan Nuansa Cendekia, 2000.

Sunarto. Televisi, Kekerasan dan Perempuan. Television, violence and Women Jakarta: Kompas,2009.

Thornham, Sue. Teori Feminis dan Cultural Studies. Feminism Theories and Cultural Studies Yogyakarta: Jalasutra, 2000.

Woolf, Virginia. “A Room of One’s Own (1929)”, https://victorianpersistence. files.2013. 